\title{
Adaptation, production, and biotechnological potential of cold-adapted proteases from psychrophiles and psychrotrophs: recent overview
}

\author{
Junaid Furhan (1)
}

\begin{abstract}
Background: Proteases or peptidases are an imperative class of hydrolytic enzymes capable of hydrolyzing large proteins into smaller peptides. The cold-adapted proteases show higher catalytic capacity in low temperatures as well as stability in alkaline conditions and appear as strong contenders for various applications in special industries.

Main body: In the past few decades, the interest in cold-adapted microorganisms producing cold-adapted proteases has increased at an exciting rate, and many of them have emerged as important biotechnological and industrial candidates. Industrial proteases are largely supplied from various types of microorganisms than plant or animal sources. Among diverse microbial sources, psychrophiles and psychrotrophs inhabiting permanently or partially cold environments have appeared as rich sources of cold-adapted proteases.

Short conclusion: The present review focuses on recent sources of cold-adapted protease producers along with the molecular adaptation of psychrotrophs and psychrophiles. The recent knowledge on production, kinetic properties, purification, and substrate specificity of cold-adapted proteases has been summarized. Recent advances in cold-adapted protease gene cloning and structural studies are also described. Moreover, the prospective applications of cold-adapted proteases are discussed which can help in evaluating their industrial potential.
\end{abstract}

Keywords: Cold-adapted proteases, Enzymes, Psychrophiles, and Psychrotrophs

\section{Background}

Most of the Earth's biosphere is covered by cold blanket, and temperature at such cold ecosystems typically tends to be below $5{ }^{\circ} \mathrm{C}$. These cold habitats include to a great extent, oceans that envelop $70 \%$ of the Earth's surface, polar regions contained by the Arctic circle, high peaks of Alps and rocky mountains, Himalayan regions, and different layers of Earth's atmosphere, and to some degree-refrigerator, deep-freezers, and other cold appliances $[1,2]$. All these natural and man-made habitats collectively cover $85 \%$ of the Earth and colonize a large number of cold-adapted microorganisms particularly

Correspondence: junaidfurhan86@gmail.com

Department of Microbiology, SKIMS Medical College-Hospital, Bemina, Srinagar, Jammu and Kashmir 190017, India archaea, bacteria, fungi, viruses, and yeasts, broadly subdivided as psychrophiles and psychrotrophs/psychrotolerants [3]. These cold-adapted microorganisms have proven to be more economical and eco-friendlier when compared with microorganisms operating at normal or higher temperatures. In the past three decades, the broad biotechnological potential of cold-adapted microorganisms and their enzymes has been robustly documented. A wide variety of commercial and industrially important enzymes especially amylases, lipases, and proteases have been sourced from cold-adapted microorganisms [4]. The worldwide industrial market for enzymes has reached just about $\$ 5.5$ billion in 2018 [5], and the worldwide market for food enzymes alone has grown to \$1.8 billion during 2017 [6]. Proteases from 
microbial sources are vital industrial enzymes accounting for $60 \%$ of the overall sale of enzymes globally and are known to hold the prime share of the detergent enzyme market [7].

Proteases represent imperative classes of hydrolytic enzymes that breakdown large proteins into smaller peptides and amino acids. Historically, proteases have been extensively used in detergent and food industries [8]. In recent times, proteases have shown biotechnological potential in a wide range of new industrial applications. Cold-adapted proteases represent vital a kind of enzymes; they have high catalytic efficiency at high temperatures and low thermostability in cold conditions which provides an advantage over the enzymes derived from mesophiles. Due to the advanced features of cold-adapted microorganisms and their cold-adapted enzymes, more attention has been paid towards the utilization of their potential for industrial applications during the last few years [9]. Researchers are continuously exploring various new aspects of cold-adapted proteases carrying novel properties to meet the rising demand of industrial sectors. Therefore, keeping the increasing literature in view, the present review summarizes the present status of recent resources, characteristics, and prospective applications of cold-adapted proteases from psychrophiles and psychrotrophs. Recent developments in gene cloning and structural studies of cold-adapted proteases which have proven to be one step forward in obtaining more robust proteases have also been discussed (Fig. 1).

\section{Main text}

Diverse sources of cold-adapted protease producing microorganisms

Since the first report on protease-producing psychrophilic Escherichia freundii of soil origin [10], not many protease-producing psychrophiles and psychrotrophs were detailed until the late 1990s. Since the beginning of the 21st century, work on cold-adapted proteases increased at an exciting rate, and they have been isolated and characterized by microbial diversities of coldadapted bacteria, yeast, and fungi. The cold-adapted protease producers are not limited to low-temperature environments only but are spread nearly among all types of environments. In recent times, Antarctic cold habitats such as deep-sea sediment, Prydz Bay [11]; soil samples, King George Island [12-15]; seawater and krill [16]; marine water, Casey Station [17]; and penguin feathers [18] have been explored for isolation of cold-adapted protease-producing microorganisms. Other cold environments inhabiting cold-adapted protease-producing microorganisms are Japanese deep-sea water [19], yellow sea $[20,21]$, Ikka Fjord and surficial sediments in Greenland [22], deep-sea mud in Eastern Indian Ocean [23], and Bolu Mountain and Erzurum soil in Turkey $[24,25]$. Cold-adapted protease producers have been isolated from soil samples of various Indian Himalayan regions such as Lahaul and Spiti [26], Kashmir apple garden [27], Thajiwas glacier [28], Gangotri glacier [29], and Wular Lake [30]. Other sources used for isolation of cold-adapted protease producers include an underground water sample of abandoned silver and lead mine

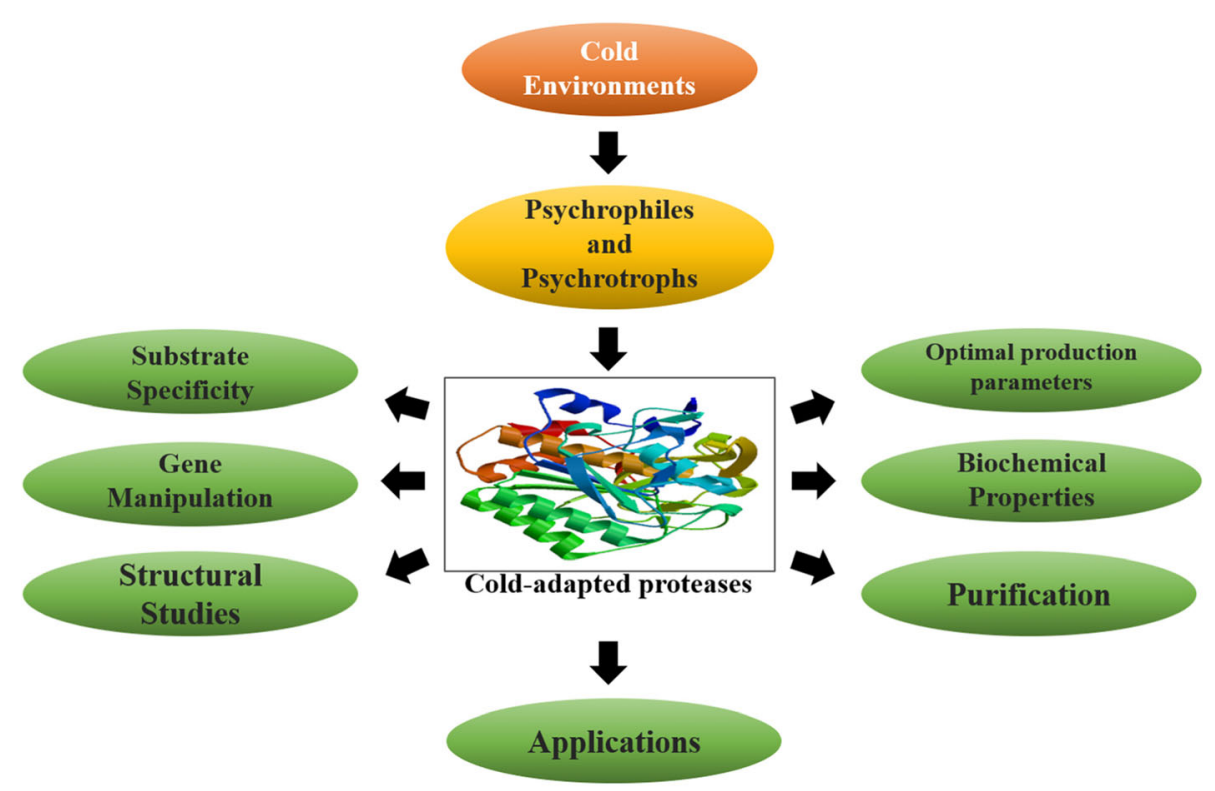

Fig. 1 Flow diagram outlining the study criteria 
Table 1 Cold-adapted microorganisms known to produce coldadapted proteases (published from 2010 onwards)

\begin{tabular}{|c|c|c|c|c|c|}
\hline $\begin{array}{l}\text { Microorganisms producing cold- } \\
\text { adapted proteases }\end{array}$ & Source of isolation & $\overline{\text { Reference }}$ & $\begin{array}{l}\text { Microorganisms producing cold- } \\
\text { adapted proteases }\end{array}$ & Source of isolation & Reference \\
\hline Bacteria & & & Glaciozyma antarctica & Antarctic marine water & {$[17]$} \\
\hline Acinetobacter sp. & Himalayan cold soil & {$[26]$} & Goffeauzyma gilvescens & Antarctic soil & {$[14]$} \\
\hline Arsukibacterium ikkense & Ikka Fjord, Greenland & {$[22]$} & Naganishia globosa & Antarctic soil & {$[14]$} \\
\hline \multirow[t]{2}{*}{ Arthrobacter sp. } & \multirow{2}{*}{$\begin{array}{l}\text { Arctic marine and } \\
\text { terrestrial samples }\end{array}$} & \multirow[t]{2}{*}{ [33] } & Naganishia adeliensis & Antarctic soil & {$[14]$} \\
\hline & & & Naganishia albida & Antarctic soil & {$[14]$} \\
\hline Bacillus sp. & Antarctic soil & {$[12]$} & \multirow{2}{*}{ Sporobolomyces roseus } & \multirow{2}{*}{$\begin{array}{l}\text { Water of disused silver } \\
\text { and lead mine }\end{array}$} & \multirow[t]{2}{*}{ [31] } \\
\hline Bacillus sp. & Apharwat glacier & {$[34]$} & & & \\
\hline Bacillus subtilis & Wular Lake & {$[30]$} & \multirow[t]{2}{*}{ Yamadazyma spp. } & \multirow{2}{*}{$\begin{array}{l}\text { Water, leaf, and grass } \\
\text { from mountain }\end{array}$} & \multirow[t]{2}{*}{ [24] } \\
\hline Chryseobacterium sp. & Natural and artificially & {$[32]$} & & & \\
\hline
\end{tabular}

Flavobacterium cold environments

Flavobacterium sp.

Flavobacterium sp.

Flavobacterium sp.

Halobacillus sp.

Lysinibacillus fusiformis

Lysobacter sp.

Mycoplana sp.

Planococcus sp.

Planomicrobium sp.

Pseudomonas sp.

Pseudomonas sp.

Pseudomonas sp.

Pseudomonas aeruginosa

Pseudomonas lundensis

Pseudoalteromonas sp.

Pseudoalteromonas sp.

Pseudoalteromonas sp.

Pseudoalteromonas arctica

Pseudoalteromonas

haloplanktis

Pseudoxanthomonas sp.

Serratia sp.

Serratia marcescens

Stenotrophomonas sp.

Stenotrophomonas sp.

Stenotrophomonas maltophilia

Fungi

$$
\begin{aligned}
& \text { Geomyces pannorum } \\
& \text { Penicillium nalgiovense }
\end{aligned}
$$

Yeast

Cryptococcus victoriae
Table 1 Cold-adapted microorganisms known to produce coldadapted proteases (published from 2010 onwards) (Continued)

[31] and cold food products and storage facilities [32]. Table 1 shows some recently isolated cold-adapted protease-producing microorganisms. Using a novel approach for enrichment, four different genera of coldadapted protease-producing bacteria were isolated collectively from Norwegian marine and terrestrial samples [33]. Similarly, a swift and direct screening method was adapted, and fifteen cold-adapted protease-producing bacterial strains belonging to two different genera were isolated from the Arctic and Antarctic region [35]. Recently, the assortment of culturable psychrotrophic and psychrophilic bacteria from three sub-glacial Himalayan lakes was examined for cold-adapted enzymes and many cold-adapted protease-producing Bacilli belonging to different families were isolated [38].

\section{Environmental adaptation and survival strategies of cold- adapted microorganisms}

Psychrophiles and psychrotrophs have accumulated a multiplicity of approaches and mechanisms that help them in enduring and inhabiting environments that are exposed to permanent or partial cold temperatures [41]. The cold ecosystems expose microorganisms to harsh and unusual conditions were maintaining the structural integrity, and normal functioning of a cell is dependent upon the disposal of the fractional part of the water from the intracellular space [42]. There has not been any clear lower temperature limit for cold-adapted microorganisms; however, in a permafrost bacteria, reproduction has been reported at $-12{ }^{\circ} \mathrm{C}$ and metabolic function at $-20{ }^{\circ} \mathrm{C}$ [43]. Microbiologists have reported lichen Umbilicaria aprina from Antarctica that carries photosynthesis at $-17^{\circ} \mathrm{C}$ [44], and yeast Rhodotorula glutinis that causes frozen food spoilage at $-18^{\circ} \mathrm{C}$ [45]. To overcome the negative influence of cold temperatures on normal cellular functioning and interactions, several tactical approaches and mechanisms are maintained by coldadapted microorganisms [46, 47]. They manage to curb ice crystal growth and ice recrystallization by producing 
small antifreeze or ice-binding (AFP) proteins which in turn lowers the freezing point by adsorbing to ice and arrest the process of freezing [48]. The ice-nucleating (IN) proteins can prevent the rapid cooling of water by inducing the crystallization of ice at temperatures close to the melting point [49]. Cold-shock proteins (CSPs) are small, single-stranded, and are encoded by the most important up-regulated gene and appear to be a further significant feature of cold-adapted microorganisms. They bind to nucleic acid and help in regulating a variety of cellular processes such as folding of proteins, transcription, translation, and fluidity of membranes [50, 51]. Another type of protein known as cold acclimation proteins (CAPs) is highly manufactured in cold-adapted microorganisms in response to low temperature for maintaining cell cycle and growth [51, 52]. Cold-adapted fungi and yeast have been reported to stockpile polyunsaturated fatty acids in high levels for maintaining membrane fluidity at low temperatures $[53,54]$. Organic osmolytes or compatible solutes are accumulated by various coldadapted microorganisms to prevent cell contraction and water loss by reinstating osmotic balance during freezing. Besides, they lower the freezing point and the colloidal glass transition temperature ( $\mathrm{Tg}$ ) and also stabilize proteins and membranes at lower temperatures [55]. Some cold-adapted bacteria produce multifunctional extracellular polymeric substances that play a significant role in restraining ice growth and ice-recrystallization. Moreover, they protect against osmotic stress and desiccation damage caused by freezing [56, 57]. Similarly, chaperons produced in some cold-adapted microorganisms help in promoting the folding and stability of proteins and also play a role in the deterioration of genetic material [58].

\section{Optimization of production parameters of cold-adapted microbial proteases}

Traditionally, the production of cold-adapted proteases from cold-adapted microorganisms has been greatly influenced by nutritional, environmental, and physicochemical parameters $[4,59]$. Owing to better management of environmental factors, submerged fermentation has been exploited more than solid-state fermentation for cold-adapted protease production. Approximately $40 \%$ of the production cost of industrial enzymes is accounted for by the usage of growth medium; therefore, it is important to identify and supply cost-effective media for the production of cold-adapted proteases [1]. There has not been any particular defined medium recognized for the optimal production of cold-adapted proteases as every cold-adapted microorganism has its own unique nutritional, environmental, and physicochemical requirements.

\section{Source of growth media}

Nutritional factors such as carbon and nitrogen sources are important components of media that stimulate microbial growth and protease production. Enhanced protease production by Chryseobacterium sp. was observed when starch $(10 \mathrm{~g} / \mathrm{L})$ was used as the carbon source and urea $(5 \mathrm{~g} / \mathrm{L})$ as a nitrogen source in the growth media [32]. Fructose in presence of skim milk was the best carbon source (2.4 fold increase), and tryptone in presence of skim milk (1.7-fold increase) was the best nitrogen source for protease production by Pseudoalteromonas arctica [13]. For psychrotrophic Sporobolomyces roseus, glucose was the best carbon source, whereas other sources like yeast extract, beef extract, and BSA showed a lower effect on protease production [31]. The highest cold-adapted protease production by psychrotolerant Bacillus subtilis [30], Chryseobacterium sp. [32], and Stenotrophomonas maltophilia [29] was observed in medium supplemented with casein as substrate source. Lactose and soya bean were the best carbon and nitrogen source respectively, whereas TSB was found to be the best medium for protease production by psychrotolerant Stenotrophomonas sp. [28]. For Bacillus sp., glucose was found to be the best carbon source, whereas skimmed milk was found to be the best substrate for optimal protease production [34].

\section{Incubation time}

Incubation time plays a vital role in affecting the protease production by various cold-adapted microorganisms, and they can be either growth-dependent or growthindependent. The cold-adapted protease production by Chryseobacterium sp. was observed to be growthdependent, and the highest production was achieved after 6 days of incubation [32]. The Cryptococcus victoriae produced maximum cold-adapted protease for immobilized cells $(13.4 \mathrm{U} / \mathrm{ml})$ and free cells $(12.1 \mathrm{U} / \mathrm{ml})$ after 72 and $96 \mathrm{~h}$ of incubation respectively [25]. The extracellular protease production by Planococcus sp. started at an early stage of the stationary phase, increased progressively, and reached the maximum at the late stationary phase (48-56 h) [60]. Kuddus and Ramteke [29] observed that protease production by Stenotrophomonas maltophilia was not interrelated with growth and it reached a peak of $49 \mathrm{U} / \mathrm{ml}$ at $120 \mathrm{~h}$ of incubation. For Bacillus subtilis and Bacillus sp., the highest protease production was observed at $110 \mathrm{~h}$ and $30 \mathrm{~h}$ of incubation respectively [30, 34]. The protease activity of another strain of Bacillus sp. was correlated with cell growth which increased sharply at $16 \mathrm{~h}$ and reached a maximum after $60 \mathrm{~h}$ of incubation [12]. Maximum alkaline protease production by Stenotrophomonas sp. was reported at $32 \mathrm{~h}$ of incubation [28]. 


\section{Incubation temperature}

Temperature is a significant parameter that has to be controlled and varies greatly between cold-adapted microorganisms for maximum protease production and cell growth. Both free and immobilized cells by Cryptococcus victoriae showed maximum protease and biomass production at $15^{\circ} \mathrm{C}$ [25]. A similar temperature of $15^{\circ} \mathrm{C}$ was required for maximum protease production by Bacillus subtilis [30] and Pedobacter cryoconitis [61]. For Chryseobacterium sp., the optimal temperature for growth and protease production was $28^{\circ} \mathrm{C}$ and $5^{\circ} \mathrm{C}$ respectively [32]. The maximum temperature for growth and protease production by Planococcus sp. was $25^{\circ} \mathrm{C}$ and $20^{\circ} \mathrm{C}$ respectively [60]. A similar temperature of $20^{\circ} \mathrm{C}$ was required for maximum protease production by Bacillus sp. [34].

\section{Culture $\mathrm{pH}$}

It is well known that enzymatic processes and transportation of various components across the cell membrane are influenced by culture $\mathrm{pH}$. Generally, most of the coldadapted microorganisms are known to yield maximum enzyme in neutral to alkaline $\mathrm{pH}$ range. The maximum protease production for both free and immobilized cells by Cryptococcus victoriae was optimal at $\mathrm{pH} 8.0$ [25]. The specific enzyme activity in Chryseobacterium sp. was found to be highest at pH 7.0 [32]. For Bacillus sp. and Bacillus subtilis, maximum protease was secreted at an alkaline $\mathrm{pH}$ of 9.0 and 10.0 respectively [30,34]. The highest protease yield of $62.2 \mathrm{U} / \mathrm{ml}$ by Stenotrophomonas maltophilia was attained at pH 9.0 [29].

\section{Effect of various metal ions}

Cold-adapted protease production has also been affected by the presence of various metal ions in the media. Mageswari et al. [32] reported that a concentration of $0.02 \%$ $\mathrm{ZnSO}_{4}$ and $\mathrm{CaCl}_{2}$ in the medium resulted in increased protease production, whereas $\mathrm{FeCl}_{3}$ and $\mathrm{KCl}$ had no influence on protease production by Chryseobacterium sp. For Stenotrophomonas sp., $\mathrm{Mg}^{2+}, \mathrm{Mn}^{2+}$, and $\mathrm{Ca}^{2+}$ at a concentration of $5 \mathrm{mM}$ displayed maximum protease production, but $\mathrm{Zn}^{2+}, \mathrm{Cu}^{2+}$, and $\mathrm{Co}^{2+}$ robustly repressed the protease production. Moreover, the combined supply of $\mathrm{Mg}^{2+}$, $\mathrm{Mn}^{2+}$, and $\mathrm{Ca}^{2+}$ showed enhanced protease production than adding them independently [28].

Furthermore, finding the relationship between various variables is necessary to develop an economical and optimal bioprocess for the industrial interest of cold-adapted proteases. The demand for cold-adapted enzymes and their related products is ever-increasing, and large-scale fermentation of cold-adapted microorganisms can be very useful for meeting the industrial requirements. Classical methods have either been time-consuming or have not been able to find accurate optimum conditions. The Colwellia sp.-derived cold-adapted protease showed a 3.0-fold enhancement in production via response surface methodology [59]. Recently, Białkowska et al. [31] reported an approximately 4.0-fold increase in protease production by combining various sources via the regression model. In another study, Han et al. [13] reported a 15 -fold improvement in protease production by Pseudoalteromonas arctica in a mineral optimized medium using a statistical approach and fed-batch culture. These advanced approaches can help in calculating the most favorable production conditions in any given set up, which can be very beneficial for large-scale production of cold-adapted proteases in the future.

\section{Biochemical properties of cold-adapted microbial proteases}

In the past couple of decades, cold-adapted proteases from cold-adapted microorganisms have been studied comprehensively so that they can be applied for particular applications based on their properties. For industrial purposes, cold-adapted proteases should possess strong activity and stability under reasonably extreme conditions. Cold-adapted proteases have shown optimal activity over a broad range of temperature and $\mathrm{pH}$, mostly depending on the character of protease-producing coldadapted microorganisms. In recent times, the cardinal temperature of cold-adapted proteases by psychrophiles and psychrotrophs has been reported between 10 and $60^{\circ} \mathrm{C}$. The optimum $\mathrm{pH}$ for their activity typically ranges in between alkaline $\mathrm{pH}$ of 7.0-10.0, with few reports on acidic and neutral $\mathrm{pH}$ for the highest activity. An aspartic protease from Geomyces pannorum and the coldadapted protease from yeast Sporobolomyces roseus showed highest activity in $\mathrm{pH} 3.0$ and 4.0 respectively $[15,32]$. A variety of metal ions, detergents, and reagents have shown the varying effect on protease activity, some of them behaving as inhibitors while some act as enhancers depending on their interaction with particular protease. The metal ion $\mathrm{Mn}^{2+}$ inhibited the activity of metalloprotease by Colwellia sp. [62] but enhanced the activity of serine protease by Acinetobacter sp. [63]. Based on effects of commonly used inhibitors like PMSF, EDTA, EGTA, and Pepstatin A, proteases are classified into serine, metallo, aspartic, and other types accordingly. The various significant properties of cold-adapted proteases are summarized in Table 2.

The stability of proteases under the wide range of temperature and $\mathrm{pH}$ is essential for their industrial applications, especially as detergent additives. The Planococcus sp.-derived cold-adapted protease was stable at 10 ${ }^{\circ} \mathrm{C}$ for $2 \mathrm{~h}$ and in a broad $\mathrm{pH}$ range of $5.0-12.0$ for 30 min. However, there was a $93 \%$ activity loss at $35{ }^{\circ} \mathrm{C}$ after $2 \mathrm{~h}$, but $80 \%$ of activity was retained within the $\mathrm{pH}$ range of 5.0-12.0 after $30 \mathrm{~min}$ [23]. For Bacillus subtilis protease, stability was observed in alkaline $\mathrm{pH}$ of 7.0- 
11.0 for $1 \mathrm{~h}$ and retained $63 \%$ of activity at $30{ }^{\circ} \mathrm{C}$ for $3 \mathrm{~h}$ at $\mathrm{pH} 10.0$ [30]. Alkaline protease from Stenotrophomonas sp. was stable in the $\mathrm{pH}$ range of $6.8-12.0$ and the temperature range of $15-30{ }^{\circ} \mathrm{C}$ for $1 \mathrm{~h}$ at $\mathrm{pH} 10.0$, retaining 90\% of activity in both conditions [28]. The coldadapted proteases from diverse cold-adapted microorganisms vary in thermal and alkaline stability and have been reviewed from time to time [15, 21, 60, 63]. These broad-spectrum properties of cold-adapted proteases make them an interesting candidate for numerous applications under diverse conditions.

\section{Purification of cold-adapted microbial proteases}

Cold-adapted protease producers are initially recognized based on different screening techniques followed by purification of their enzymes up to different levels. The molecular weight is usually determined via SDS-PAGE. Cold-adapted proteases vary extensively in their size range, the lowest being reported from Bacillus amyloliquefaciens protease, i.e., $23 \mathrm{kDa}$ [65], and highest from Curtobacterium luteum protease, i.e., $115 \mathrm{kDa}$ [66]. They are subjected to multistep techniques for attaining various levels of purification folds. Mostly, ammonium sulfate precipitation has been used for initial concentration, but in some cases, ultrafiltration and acetone precipitation have also been used. Within the past few years, novel techniques have been applied for increasing the yield percentage and purification fold of coldadapted proteases (Table 3). The importance of purified cold-adapted proteases has been frequently endorsed in a variety of applications at the biotechnological scale.

\section{Substrate specificity of cold-adapted microbial proteases}

One of the imperative features of cold-adapted proteases is their capability to distinguish between competing substrates, and the function of these cold-adapted enzymes is highly dependent on their substrate specificity. In general, cold-adapted proteases are known to be active against various native proteins and different types of natural and synthetic substrates, displaying wide substrate specificity. The extracellular cold-adapted alkaline peptidase produced by Acinetobacter sp. exhibited substrate specificity towards various protein substrates. The highest activity was found towards casein and BSA followed by azocasein and skim milk, whereas gelatin showed the lowest activity [63]. A thermolabile subtilisin-like protease (P6) from Pseudoalteromonas sp. hydrolyzed synthetic substrateSucc-AAPF-pNa - and natural substrate-succinylated casein-but showed no activity on Succ-AAVA-pNa [16]. Another thermolysin-like protease (HSPA) secreted by Halobacillus sp. hydrolyzed various soluble and insoluble proteins, such as feather, elastin, collagen, hemoglobin, and BSA but proteins such as casein and gelatin were found to be suitable substrates. Among various synthetic substrates tested, HSPA exhibited higher hydrolytic activity on FA-Gly-Phe- $\mathrm{NH}_{2}$ and FA-Gly-Leu- $\mathrm{NH}_{2}$, but almost no activity was observed on FA-Ala-Arg-OH and FA-GluGlu-OH. Results signify that protease HSPA preferred Leu more than Phe at the $\mathrm{P}_{1}{ }^{\prime}$ position and demonstrated lower affinity towards alkaline and acid $P_{1}^{\prime}$ residues [37]. The hydrolytic activity of a cold-adapted serine protease produced by Chryseobacterium sp. was highest with casein followed by gelatin and BSA, whereas egg albumin was least hydrolyzed [32]. For cold-adapted serine peptidase by Lysobacter sp., the highest activity was observed on azocasein followed by gelatin and feather powder, whereas casein, BSA, and azokeratin showed lowest enzymatic activity [18]. An aspartic protease produced by psychrotrophic yeast Sporobolomyces roseus showed the highest activity against natural protein substrates such as urea-denatured and native hemoglobin, but lower activity was observed against synthetic substrates such as N-succinyl-Ala-Ala-Pro-Phe-p-nitroanilide and $\mathrm{N}$ succinyl-Ala-Ala-Pro-Leu-p-nitroanilide [31]. The specific activity of another aspartic protease produced by psychrophilic fungus Geomyces pannorum was highest towards hemoglobin followed by $\mathrm{k}$-Casein and lowest towards cytochrome c [15]. The broad substrate specificity of cold-adapted proteases can be valuable for industrial applications, especially in bioremediation processes carried at low temperatures.

\section{Recent progress in gene cloning and protein engineering} of cold-adapted microbial proteases

The extensive utilization of proteases in various industries has increased the requirement of novel coldadapted proteases that possess high catalytic efficiency and thermostability together at low temperatures. Generally, higher catalytic efficiency at lower temperatures leads to weaker thermostability within most of the coldadapted proteases, a common setback that deters their scope of utilization in industries. Keeping that in view, various new approaches like protease gene cloning, protein engineering, deletion mutagenesis, direct evolution, and site-directed mutagenesis have been successfully implemented to enhance the thermostability and catalytic proficiency of cold-adapted proteases. A subtilisin-like protease gene encoding a precursor protein was cloned and expressed in E. coli. The recombinant protein (P6) exhibited elevated catalytic efficiency than Carlsberg protease at a temperature range of $5-25{ }^{\circ} \mathrm{C}$ [16]. Similarly, the protease gene (cpls8) encoding an intracellular protease (CPLS8) from Planococcus sp. was cloned and expressed in E. coli. The recombinant CPLS8 illustrated remarkable alkali-stability at a $\mathrm{pH}$ range of $\mathrm{pH} 5.0-12.0$ and higher catalytic efficiency at a temperature range of $5-35^{\circ} \mathrm{C}$ which makes CPLS8 worthy as an industrial product [23]. The gene encoding cold-adapted serine 
Table 2 Biochemical properties of cold-adapted proteases (published from 2010 onwards)

\begin{tabular}{|c|c|c|c|c|c|}
\hline Microbial source & Protease type & Strong inhibitors & Stimulators/enhancers & $\begin{array}{l}\text { Optimum } \\
\text { temp./pH }\end{array}$ & Reference \\
\hline Acinetobacter sp. & $\begin{array}{l}\text { Serine } \\
\text { peptidase }\end{array}$ & PMSF, EDTA, EGTA, 2-ME, Pepstatin A, DTT, and $\mathrm{Hg}^{2+}$ & $\mathrm{Ca}^{2+}, \mathrm{Mn}^{2+}, \mathrm{Na}^{+}, \mathrm{Zn}^{2+}$ & $40 / 9$ & [63] \\
\hline Bacillus sp. & Metalloprotease & $\mathrm{Cu}^{2+}, \mathrm{Zn}^{2+}, \mathrm{Hg}^{2+}, \mathrm{EDTA}$, and SDS & $\mathrm{Mg}^{2+}$ and $\mathrm{Ca}^{2+}$ & $40 / 7.4$ & [12] \\
\hline Bacillus sp. & Metalloprotease & EDTA, EGTA $\mathrm{Ca}^{2+}, \mathrm{Cu}^{2+}, \mathrm{Mg}^{2+}, \mathrm{K}^{+}, \mathrm{Zn}^{2+}$ & $\mathrm{Mn}^{2+}$ & 20/9 & [34] \\
\hline Bacillus subtilis & Serine protease & $\mathrm{Mg}^{2+}, \mathrm{Pb}^{2+}, \mathrm{Mn}^{2+}, \mathrm{Al}^{3+}$, and $\mathrm{Fe}^{2+}$ & $\mathrm{Cu}^{2+}$ and $\mathrm{Ca}^{2+}$ & $15 / 10$ & [30] \\
\hline $\begin{array}{l}\text { Chryseobacterium } \\
\text { sp. }\end{array}$ & Serine protease & $\begin{array}{l}\text { Butanol, acetonitrile, isopropanol, ethyl acetate, } \\
\text { tetrahydrofuran, } \mathrm{Hg}^{2+}, \mathrm{Zn}^{2+} \text {, and } \mathrm{Cu}^{2+}\end{array}$ & $\mathrm{Na}^{+}, \mathrm{Ca}^{2+}, \mathrm{Ba}^{2+}$, and $\mathrm{Fe}^{2+}$ & $\begin{array}{l}10 / 7.0- \\
8.0\end{array}$ & [32] \\
\hline $\begin{array}{l}\text { Geomyces } \\
\text { pannorum }\end{array}$ & $\begin{array}{l}\text { Aspartic } \\
\text { protease }\end{array}$ & $\begin{array}{l}\text { Methanol, isopropanol, } \mathrm{DMSO}, \mathrm{Mg}^{2+}, \mathrm{Fe}^{2+}, \mathrm{Ca}^{2+} \text {, and } \\
\mathrm{Zn}^{2+}\end{array}$ & $\mathrm{Co}^{2+}, \mathrm{Mn}^{2+}, \mathrm{Cu}^{2+}$, and $\mathrm{Ni}^{2+}$ & $60 / 3.0$ & [15] \\
\hline Halobacillus sp. & $\begin{array}{l}\text { Thermolysin-like } \\
\text { protease }\end{array}$ & EGTA, $\mathrm{Cu}^{2+}$, EDTA, 1,10-phenanthroline, and $\mathrm{Ni}^{2+}$ & $\mathrm{Mn}^{2+}, \mathrm{Ca}^{2+}, \mathrm{Mg}^{2+}$, and $\mathrm{Ba}^{2+}$ & $30 / 8$ & [37] \\
\hline Lysobacter sp. & $\begin{array}{l}\text { Serine } \\
\text { peptidase }\end{array}$ & PMSF, EDTA, and $\mathrm{Zn}^{2+}$ & $\begin{array}{l}\mathrm{Ca}^{2+}, \mathrm{Mg}^{2+}, \mathrm{Ba}^{2+}, \mathrm{Na}^{+}, \mathrm{NH}_{4}^{+}, \\
\text {and isopropyl alcohol }\end{array}$ & $40 / 9.0$ & [18] \\
\hline $\begin{array}{l}\text { Penicillium } \\
\text { nalgiovense }\end{array}$ & Serine protease & PMSF, SDS, $\mathrm{Mn}^{2+}$, and $\mathrm{Zn}^{2+}$ & $\mathrm{Ca}^{2+}$ and $\mathrm{Mg}^{2+}$ & $35 / 8$ & [40] \\
\hline Planococcus sp. & Serine protease & $\begin{array}{l}\text { PMSF, DEPC, EDAC, urea, SDS, EDTA, } \mathrm{Co}^{2+}, \mathrm{Zn}^{2+}, \mathrm{Fe}^{3+} \text {, } \\
\text { and } \mathrm{Ni}^{2+}\end{array}$ & $\mathrm{Ca}^{2+}$ & $35 / 10$ & [23] \\
\hline Planococcus sp. & Serine protease & EDTA, PMSF, TNBS, EDAC, $\mathrm{Cu}^{2+}$, and $\mathrm{Ni}^{2+}$ & $\mathrm{Fe}^{3+}$ and $\mathrm{Ca}^{2+}$ & $35 / 10$ & [60] \\
\hline Planomicrobium sp. & Serine protease & PMSF and AEBSF & $\mathrm{Ca}^{2+}$ and $\mathrm{Mn}^{2+}$ & $35 / 9$ & [11] \\
\hline $\begin{array}{l}\text { Pseudomonas } \\
\text { aeruginosa }\end{array}$ & Serine protease & PMSF and $\mathrm{Ag}^{+}$ & $\begin{array}{l}\mathrm{Mg}^{2+}, \mathrm{K}^{+}, \mathrm{Ca}^{2+}, \mathrm{Ba}^{2+}, \text { and } \\
\mathrm{Zn}^{2+}\end{array}$ & $25 / 10$ & [21] \\
\hline $\begin{array}{l}\text { Pseudoalteromonas } \\
\text { sp. }\end{array}$ & Serine protease & PMSF, SDS, and $\mathrm{H}_{2} \mathrm{O}_{2}$ & $\mathrm{Nm}$ & $\begin{array}{l}25-35 / 8- \\
9\end{array}$ & [16] \\
\hline $\begin{array}{l}\text { Pseudoalteromonas } \\
\text { arctica }\end{array}$ & $\begin{array}{l}\text { Subtilisin-like } \\
\text { protease }\end{array}$ & Linear alkylbenzene sulfonate (LAS) and SDS & $\mathrm{Ca}^{2+}$ & $30 / 9.0$ & [64] \\
\hline $\begin{array}{l}\text { Pseudomonas } \\
\text { lundensis }\end{array}$ & Metalloprotease & $\begin{array}{l}\text { EDTA, EGTA }, \mathrm{Cu}^{2+}, \mathrm{Fe}^{3+}, \mathrm{Al}^{3+}, \mathrm{Fe}^{2+}, \mathrm{Mn}^{2+}, \mathrm{Al}^{3+} \text {, and } \\
\mathrm{CO}^{2+}\end{array}$ & $\mathrm{Na}^{+}, \mathrm{K}^{+}$, and $\mathrm{Li}^{+}$ & $30 / 10.4$ & [19] \\
\hline Serratia marcescens & Metalloprotease & EDTA, $\mathrm{MnCl}_{2}, \mathrm{CaCl}_{2}, \mathrm{CoSO}_{4}, \mathrm{HgCl}_{2}$, and $\mathrm{Na}_{2}$ & $\mathrm{Nm}$ & $40 / 8$ & [27] \\
\hline $\begin{array}{l}\text { Sporobolomyces } \\
\text { roseus }\end{array}$ & $\begin{array}{l}\text { Aspartic } \\
\text { protease }\end{array}$ & 2-Mercaptoethanol, dithiothreitol, SDS, and Pepstatin A & $\mathrm{Nm}$ & $50 / 4$ & [31] \\
\hline $\begin{array}{l}\text { Stenotrophomonas } \\
\text { sp. }\end{array}$ & $\begin{array}{l}\text { Alkaline } \\
\text { protease }\end{array}$ & $\mathrm{Zn}^{2+}, \mathrm{Cu}^{2+}$, and $\mathrm{Co}^{2+}$ & $\mathrm{Mg}^{2+}, \mathrm{Mn}^{2+}$, and $\mathrm{Ca}^{2+}$ & $15 / 10$ & [28] \\
\hline $\begin{array}{l}\text { Stenotrophomonas } \\
\text { maltophilia }\end{array}$ & $\begin{array}{l}\text { Alkaline } \\
\text { protease }\end{array}$ & $\mathrm{Co}^{2+}$ & $\mathrm{Cu}^{2+}, \mathrm{Cr}^{2+}$ & $20 / 10$ & [29] \\
\hline
\end{tabular}

$\mathrm{Nm}$ not mentioned

protease (GpPro2) of Glaciozyma antarctica was cloned and expressed in Pichia pastoris. The recombinant GpPro2 displayed low thermostability and high catalytic activity at low temperatures, making GpPro2 an interesting candidate for biotechnological exploitation [17]. A cold-adapted peptidase gene (a0301) from Lysobacter sp. was heterologously expressed in E. coli, and recombinant A03Pep1 showed characteristics suitable for industrial applications [18]. Park et al. [64] cloned the pro21717 gene encoding the psychrophilic serine protease (Pro21717) from Pseudoalteromonas arctica, and the recombinant Pro21717-CD exhibited higher activity at alkaline $\mathrm{pH}$ and low temperature. Moreover, Pro21717CD showed stability against various chemicals and detergent surfactants, making it a valuable product for commercial detergent formulations. In a recent study, the gene $A l p$ encoding serine alkaline protease of the psychrotrophic bacterium Acinetobacter sp. was cloned and expressed in E. coli. The recombinant protease (Alp) showed resistance to extreme alkaline conditions and low temperatures suggesting its potential in the detergent industry [67]. A novel aspartic protease gene $P 10$ from Geomyces pannorum was cloned and heterologously expressed in Aspergillus oryzae. The recombinant P10 showed improved stability and potential application in cheese-making [15]. Successful cloning of the coldadapted alkaline protease gene from Bacillus subtilis [30], protease gene hspa from Halobacillus sp. [37], and protease gene cpls41 from Planococcus sp. [60] has also been reported. 
Table 3 Molecular weight and purification of cold-adapted proteases (published from 2010 onwards)

\begin{tabular}{|c|c|c|c|c|}
\hline Microbial source & $\begin{array}{l}\text { Molecular } \\
\text { weight }\end{array}$ & Chromatographic techniques & $\begin{array}{l}\text { Purification fold/final } \\
\text { yield }\end{array}$ & Reference \\
\hline Acinetobacter sp. & 35 & DEAE cellulose and Sephacryl S-200 & $9.8 / 0.16$ & [63] \\
\hline Bacillus sp. & 62 & $\mathrm{Nm}$ & $3.82 / 76$ & [34] \\
\hline Bacillus subtilis & 38 & DEAE cellulose & $49.22 / 29.28$ & [30] \\
\hline Halobacillus sp. & 35 & $\begin{array}{l}\text { DEAEeSephadex, ion exchange, and Sephadex G-75 gel } \\
\text { filtration }\end{array}$ & $3077 \pm 49 / 26$ & {$[37]$} \\
\hline Lysobacter sp. & 35 & $\mathrm{Nm}$ & $2.40 / 95.6$ & [18] \\
\hline Planococcus sp. & 35.6 & His-Bind resin affinity chromatography & $\mathrm{Nm}$ & [23] \\
\hline Planococcus sp. & 43 & DEAE-Sepharose & $\mathrm{Nm}$ & {$[60]$} \\
\hline Penicillium nalgiovense & 45.2 & $\mathrm{Nm}$ & $12.1 / 82.9$ & [40] \\
\hline Pseudomonas lundensis & 46 & Gel filtration & $14 / 20$ & [19] \\
\hline Pseudomonas aeruginosa & 32.8 & DEAE-Sepharose and Sephacryl S-200 gel filtration & $10 / 60$ & [21] \\
\hline Pseudoalteromonas sp. & 34.6 & Affinity chromatography & $\mathrm{Nm}$ & [16] \\
\hline Serratia marcescens & 56 & DEAE cellulose Fraction & $9.9 / 51$ & [27] \\
\hline Sporobolomyces roseus & 31 & HiTrap SPFF, Superose 12 and Mono S & $103 / 25$ & [31] \\
\hline Stenotrophomonas sp. & 55 & DEAE-Sepharose & $18.45 / 47$ & [28] \\
\hline $\begin{array}{l}\text { Stenotrophomonas } \\
\text { maltophilia }\end{array}$ & 75 & DEAE cellulose column & $\mathrm{Nm}$ & [29] \\
\hline
\end{tabular}

$\mathrm{Nm}$ not mentioned

Earlier, Yan et al. [68] cloned and expressed the mcp03 gene encoding cold-adapted halophilic protease (MCP-03) of the psychrotolerant Pseudoalteromonas sp., and the recombinant MCP-03 was more thermolabile and active than Carlsberg subtilisin at low temperatures. The deletion mutagenesis illustrated that the C-terminal PPC domains were obligatory for the higher thermostability of MCP-03 but affected the catalytic efficiency and caused restraint in the activity. However, recently, Zhao and Feng [69] engineered several variants of mesophilic alkaline serine protease from Bacillus pumilus by a combination of direct evolution and site-directed mutagenesis. The P9S/K27Q and P9S/T162I variants showed a 2.6-fold improvement in catalytic efficiency ( $\mathrm{kcat} / \mathrm{km}$ ) and 5-fold enhancement in specific activity respectively than wild-type enzyme at $15^{\circ} \mathrm{C}$, without showing any negative effect on thermostability. The results suggested that by advanced engineering techniques, it is possible to improve both catalytic efficiency and thermostability together at the same time without causing any restraint on each other's activity.

\section{Structural analysis and molecular modeling of cold- adapted microbial proteases}

The principal objective regarding the structural study of cold-adapted proteases has been to develop a better understanding of their adaptation to cold temperature environments. In the past, various solved crystal structures of cold-adapted proteases have been reported that explain the structure-environment adjustment of proteins and provide valuable insights that are important for exploiting their industrial and therapeutic potential. Historically and in the present time, crystallography and homology modeling have been extensively used to resolve the structures of cold-adapted proteases. Structural comparison of cold-adapted proteases with their mesophilic and thermophilic counterparts has provided constructive facts about the molecular basis of lowtemperature adaptation [9]. Previous and recent reports conclude that cold-adapted proteases demonstrate more flexibility, have lengthier loops, have fewer salt bridges, are negatively charged amino acids, and are hydrophilic. They contain a higher number of glycine residues, whereas arginine and proline are present in lower concentrations. The surface of three-dimensional structures probably has a higher percentage of hydrophobic sidechains and contains more negatively charged residues than positively charged residues $[4,67,70]$. As the study on structural analysis of cold-adapted proteases progresses and several crystal structures are solved, the knowledge related to their low-temperature adaption keeps on advancing. A 3D model of subtilisin-like coldadapted protease (P6) from Pseudoalteromonas sp. was built and compared with the mesophilic variant (P23314) from Xanthomonas via homology modeling. By the combination of local packing analysis and sitedirected mutagenesis, it was determined that the Ala residue might be responsible for cold-adaptation of P6. Moreover, the Ala residue via laboratory evolution was found to be accountable for cold adaptation of the 
mesophilic P23314 also. Therefore, evaluating the position of this Ala residue might provide valuable information about substrate specificity and temperature adaptation of subtilisin-like proteases [16]. In another study, a homologous model of Planococcus sp.-derived cold-adapted protease (CPLS8) was built using Swissmodel by comparing the crystal structure of subtilisin from Bacillus clausii. Furthermore, the secondary and tertiary structures of CPLS8 were analyzed, predicted, and compared with three different structures of mesosubtilisin protease (MSP), thermo-serine protease (TSP), and a thermostable serine protease (ETSP). The intramolecular interactions of CPLS8 were found to be weak, and loosely packing was observed as compared to mesoand thermo-counterparts. In comparison with TSP and ETSP, the CPLS8 had a higher number of amino acid residues and a reduced number of hydrogen bonds. These differences possibly explain the low-temperature adaptation of CPLS8 [23]. Pereira et al. [18] determined the crystal structure of a cold-adapted serine peptidase (A03Pep1) from Lysobacter sp. The comparative studies illustrated that A03Pep1 had less deep and wider binding pocket than mesophilic peptidase AprV2; this difference might be due to higher activity of A03Pep1 at low temperatures. Recently, a crystal structure of catalytic domain from cold-adapted protease (Pro21717) of psychrophilic Pseudoalteromonas arctica was determined at a resolution of $1.4 \AA$. The Pro21717-CD structural analysis concluded that a co-purified peptide at the substrate-binding site showed unanticipated electron density which gave an idea about the substrate recognition and binding mode of cold-adapted Pro21717. Several other factors like rich active-site loop content, broad substrate pocket size, and structural flexibility assisted further in the better understanding of low-temperature adaptation and industrial potential of Pro21717 [64]. These reports demonstrate that structural analysis and molecular modeling of cold-adapted proteases provide a better understanding of their low-temperature adaptation, which can be exploited for improving their quality and scope in various industries. Moreover, comparing the structures of cold-adapted proteases with their hyperthermophilic counterparts can also be considered in the future for more valuable insights and deeper understanding related to low-temperature adaptation.

\section{Prospective applications of cold-adapted microbial proteases}

Modern-day biotech industries need enzymes that are eco-friendly and economically beneficial, and coldadapted proteases likely have that industrial and biotechnological potential in them. They have gained popularity over the last few decades due to the recognition of their catalytic capability at low temperatures and low thermostability at high temperatures. With advanced research, the future of cold-adapted proteases promises a higher industrial market compared to mesophilic and thermostable proteases. The recent applications of coldadapted proteases reported for various industrial sectors are described below and are also presented in tabular form (Table 4).

\section{Food industry}

Cold-adapted proteases have shown promising prospect in the food industry due to the fact that they are thermally unstable and can be selectively and rapidly inactivated when required. Moreover, these cold-adapted enzymes are beneficial due to their optimal enzymatic activity at low temperatures which eliminates the risk of microbial contamination [75, 76]. He et al. [74] reported that cold-adapted protease of Pseudoalteromonas sp. improved the taste of frozen meat better than mesophilic protease by releasing extra taste amino acids and essential amino acids. Another psychrophilic Pseudoalteromonas sp.-derived cold-adapted protease released more free amino acids from milk protein in contrast to mesophilic papain at $4{ }^{\circ} \mathrm{C}$, suggesting the extensive substrate specificity and prospective function in low-temperature food processing [59]. The cold-adapted metalloprotease from Enterococcus faecalis has been proven safe for oral administration with no side effects at all. This enzyme can be functionally used in the food industry by direct means and can improve the stability and solubility of health foods [72]. An alkaline peptidase from Penicillium chrysogenum showed the potential to be more valuable for cheese manufacturing compared to the commonly used microbial mesophilic and thermostable proteases [77]. Similarly, an aspartic protease from Geomyces pannorum showed features that are suitable for cheese-making [15]. The proteolytic enzymes secreted by Arsukibacterium $i k k e n s e$ produced bioactive peptides by degrading casein extensively, and these enzymes were suggested to be appropriate for dairy products and other functional foods [22]. The cold-adapted serine protease from Chryseobacterium sp. showed diverse properties such as lowtemperature activity and salt tolerance and was potentially applicable in meat and other food processing industries [32].

\section{Detergent industry}

Proteases with high levels of activity at low temperatures came into existence after certain limitations were found in thermostable proteases. These low-temperature proteases were introduced at the commercial level in the year 1985 as third-generation proteases [78]. The main purpose behind developing such low-temperature proteases was energy and time preservation. Besides alkali stability, a good detergent protease is expected to be stable in the 
Table 4 Prospective applications of cold-adapted proteases from psychrophiles and psychrotrophs

\begin{tabular}{|c|c|c|}
\hline Microbial source/protease & Potential application & Reference \\
\hline Acinetobacter sp. (serine protease) & Suitable for detergent formulations & [63] \\
\hline Arsukibacterium ikkense (cold-active protease) & Applicable in dairy products and other functional foods & [22] \\
\hline Bacillus sp. (metalloprotease) & Detergent additive for cold-washing & [34] \\
\hline Bacillus sp. (metalloprotease) & $\begin{array}{l}\text { Environmentally friendly feed additive to improve the production performance of farm } \\
\text { animals }\end{array}$ & [12] \\
\hline Bacillus subtilis (alkaline protease) & Biodegradation of protein rich wastes & [71] \\
\hline Bacillus subtilis (serine protease) & Detergent additive for cold washing & [30] \\
\hline Chryseobacterium sp. (serine protease) & Applicable in meat and other food processing units & [32] \\
\hline Enterococcus faecalis (metalloprotease) & Improves the stability and solubility of health foods & [72] \\
\hline Flavobacterium limicola (cold-active protease) & Primary mineralization of organic polymers in freshwater sediments & [73] \\
\hline Pedobacter cryoconitis (metalloprotease) & Bioremediation of wastewater in cold conditions & [61] \\
\hline Penicillin nalgiovense (alkaline protease) & Suitable for meat ripening purposes & [40] \\
\hline Planococcus sp. (serine protease) & Detergent additive for cold washing & {$[60]$} \\
\hline Pseudomonas aeruginosa (alkaline protease) & Cold washing detergent enzyme & {$[21]$} \\
\hline Pseudoalteromonas sp. (serine protease) & Improves the taste of refrigerated meat & [74] \\
\hline Pseudoalteromonas sp. (serine protease) & Applicable in low-temperature food processing & [59] \\
\hline $\begin{array}{l}\text { Pseudoalteromonas arctica (subtilisin-like } \\
\text { protease) }\end{array}$ & Suitable for cold-active laundry or dishwashing purposes & [64] \\
\hline Serratia marcescens (metalloprotease) & Detergent additive for cleaning purposes & {$[27]$} \\
\hline Stenotrophomonas sp. (alkaline protease) & Suitable for detergent and textile industry & {$[28]$} \\
\hline
\end{tabular}

presence of commercial detergents, oxidants, and surfactants. Microbial cold-adapted proteases along with detergents have proven to be more effective during cold washing as compared to enzyme-free detergents. At lower washing temperatures, numerous cold-adapted proteases have shown outstanding activity and stability in broad alkaline $\mathrm{pH}$ as well as compatibility with a variety of commercial detergents [30, 34, 60, 63, 64]. Also, cold-adapted alkaline proteases have shown excellent stability in commercially available surfactants and bleaches [21]. Furthermore, cold-adapted proteases along with commercial detergents have removed the proteinous matter from clothes stained with chocolate, tea, blood, egg yolk, grass, etc. at low temperatures much more efficiently as compared to enzyme-free detergents. These properties make them suitable as appropriate detergent additives for laundry industries and dishwashing purposes.

In recent times, Palo Alto (CA, USA) released two coldadapted detergent proteases (Purafect ${ }^{\circ}$ and Properase ${ }^{\circ}$ ) in the market which are active at low temperatures. Another cold-adapted detergent additive protease with market name Excellase $^{\circ}$ developed by Genencor has been launched in liquid form for dishwashing purposes [79].

\section{Textile industry}

Cold-adapted proteases might find applications in the textile industry because their actions on fabrics can reduce the harmful effects of chemicals. They can enhance the life of woolen and silk fabrics by retaining the quality of cloth after washing at lower temperatures. Reports suggest that cold-adapted protease treatment can improve the surface appearance as well as reduce the bristles of woolen fabrics and preserve the finishing of silk cloths $[27,28]$.

\section{Feed additives}

Proteases due to their extensive substrate specificity as well as reasonably advantageous activity levels at a physiologically applicable temperature and $\mathrm{pH}$ can be used as an eco-friendly feed additive for improving the manufacturing performance of animal farms. Coldadapted proteases which possess keratinolytic activity can facilitate and endorse biotechnological processing of biomaterials consisting of keratinous waste from leather and poultry industries [12].

\section{Polymer degrading}

Various species of genus Flavobacterium regulate their fatty acid composition during cold conditions which assists them in maintaining their membrane fluidity. This process helps them in degrading different organic polymers that facilitate the production of a considerable amount of extracellular protease in cold temperatures, thus playing a vital part in the prime mineralization of composite organic materials present in freshwater sediments throughout cold seasons [73]. 


\section{Bioremediation}

Proteases withstanding low temperatures may find applications in environmental biodegradation of protein-rich wastes and wastewater treatment in cold conditions [71]. Anaerobic psychrophiles from Antarctic surroundings possess an ability to thrive and produce proteases on a broad range of substrates which indicates their potential of being used for the breakdown of protein-rich substrates like night soil [80]. In another example, a psychrophilic Pedobacter cryoconitis utilized a large number of organic compounds such as oil hydrocarbons, carbohydrates, and proteins and was recommended to be suitable for the treatment of impure wastewater in cold conditions [61].

\section{Conclusion}

Cold-adapted microbial proteases are mainly characterized by low thermostability at elevated temperatures and high catalytic effectiveness at cold temperatures at which meso-variants are not active. Regardless of the widespread investigation, the knowledge about these unique enzymes is still limited. The current biotechnological era demands more novel cold-adapted proteases from psychrophiles and psychrotrophs with exciting features for industrial and research purposes. There is a need for exploring new ways for economical and large-scale production of cold-adapted proteases. The positive effects of gene cloning and protein engineering have greatly influenced the quality and production of recombinant enzymes. Further, extensive efforts are required for identifying unique and novel cold-adapted protease genes that can be tailored to attain desired results. The quantitative economic overproduction of cold-adapted proteases can be achieved by strain improvement and optimization of various production parameters along with the identification of cheaper nutrient sources. Furthermore, solving more crystal structures can provide in-depth knowledge and a better understanding about the structure-function relationship of cold-adapted proteases. Mostly, mesophilic proteases have been used for comparative structural studies. In the future, thermophilic, hyper-thermophilic, and other distinct counterparts can also be considered to explain the changes that may be associated with cold-adaptation of psychrophily and psychrotrophy. To conclude, it is likely that the present review will help in giving better insights about protease biotechnology and help in attaining more robust cold-adapted proteases in the future.

\section{Acknowledgements \\ The author is grateful to Dr. Sarika Sharma, Dean Basic Sciences Arni \\ University, Katgarh, for support and encouragement.}

\section{Authors' contributions}

The author "JF" alone is responsible for the content and writing of the paper. The author read and approved the final manuscript.
Funding

Not applicable.

Availability of data and materials

Data sharing is not applicable to this article as no datasets were generated or analyzed during the current study.

Ethics approval and consent to participate

Not applicable.

Consent for publication

Not applicable.

\section{Competing interests}

The author declares that there are no competing interests.

Received: 10 January 2020 Accepted: 14 July 2020

Published online: 28 July 2020

\section{References}

1. Kuddus M, Ahmad I (2012) Cold-active extracellular a-amylase production from novel bacteria Microbacterium foliorum GA2 and Bacillus cereus GA6 isolated from Gangotri glacier, Western Himalaya. J Genet Eng Biotechnol 10:151-159

2. Hamdan A (2018) Psychrophiles: ecological significance and potential industrial application. S Afr J Sci 114:1-6

3. Margesin R, Collins T (2019) Microbial ecology of the cryosphere (glacial and permafrost habitats): current knowledge. Appl Microbiol Biotechnol 103(6): $1-13$

4. Kasana RC (2010) Proteases from psychrotrophs: an overview. Crit Rev Microbiol 36:134-145

5. Staff BR (2018) Global markets for enzymes in industrial applications. BCC Research LLC.

6. Chen J (2018) Food enzymes: global markets. BCC Research

7. Gupta R, Beg Q, Lorenz P (2002) Bacterial alkaline proteases: molecular approaches and industrial applications. Appl Microbiol Biotechnol 59:15-32

8. Sharma KM, Kumar R, Panwar S, Kumar A (2017) Microbial alkaline proteases: optimization of production parameters and their properties. J Genet Eng Biotechnol 15:115-126

9. Joshi S, Satyanarayana T (2013) Biotechnology of cold-active proteases. Biology 2:755-783

10. Nakajima M, Mizusawa K, Yoshida F (1974) Purification and properties of an extracellular proteinase of psychrophilic Escherichia freundii. FEBS J 44:87-96

11. XiangSheng Y, XingLin C, XianZhong X, RunYing Z (2011) Cold-adaptive alkaline protease from the psychrophilic Planomicrobium sp. 547: enzyme characterization and gene cloning. 极地研究 22:49-54.

12. Park I, Cho J (2011) Production of an extracellular protease by an Antarctic bacterial isolate (Bacillus sp. JSP1) as a potential feed additive. Rev Colom Cienc Pecua 24:11-18

13. Han SJ, Park H, Kim S, Kim D, Park HJ, Yim JH (2016) Enhanced production of protease by Pseudoalteromonas arctica PAMC 21717 via statistical optimization of mineral components and fed-batch fermentation. Prep Biochem Biotechnol 46:328-335

14. Białkowska AM, Szulczewska KM, Krysiak J, Florczak T, Gromek E, Kassassir H, Kur J, Turkiewicz M (2017) Genetic and biochemical characterization of yeasts isolated from Antarctic soil samples. Polar Biol 40:1787-1803

15. Gao B, He L, Wei D, Zhang $L$ (2018) Identification and magnetic immobilization of a pyrophilous aspartic protease from Antarctic psychrophilic fungus. J Food Biochem:e12691

16. Acevedo J, Rodriguez V, Saavedra M, Munoz M, Salazar O, Asenjo J, Andrews B (2013) Cloning, expression and decoding of the cold adaptation of a new widely represented thermolabile subtilisin-like protease. J Appl Microbiol 114:352-363

17. Alias N, Mazian A, Salleh AB, Basri M, Rahman RNZRA $(2014,2014)$ Molecular cloning and optimization for high level expression of cold-adapted serine protease from antarctic yeast Glaciozyma antarctica PI12. Enzyme Res

18. Pereira JQ, Ambrosini A, Passaglia LMP, Brandelli A (2017) A new coldadapted serine peptidase from Antarctic Lysobacter sp. A03: insights about enzyme activity at low temperatures. Int J Biol Macromol 103:854-862 
19. Yang C, Wang F, Hao J, Zhang K, Yuan N, Sun M (2010) Identification of a proteolytic bacterium, HW08, and characterization of its extracellular coldactive alkaline metalloprotease Ps5. Biosci Biotechnol Biochem 74:1220-1225

20. Zhang SC, Sun M, Li T, Wang QH, Hao JH, Han Y, Hu XJ, Zhou M, Lin SX (2011) Structure analysis of a new psychrophilic marine protease. PLoS One 6:e26939

21. Hao JH, Sun M (2015) Purification and characterization of a cold alkaline protease from a psychrophilic Pseudomonas aeruginosa HY1215. Appl Biochem Biotechnol 175:715-722

22. De Gobba C, Tompa G, Otte J (2014) Bioactive peptides from caseins released by cold active proteolytic enzymes from Arsukibacterium ikkense. Food Chem 165:205-215

23. Zhang H, Mu H, Mo Q, Sun T, Liu Y, Xu M, Wang H, Dai Y, Lu F (2016) Gene cloning, expression and characterization of a novel cold-adapted protease from Planococcus sp. J Mol Catal B Enzym 130:1-8

24. Daskaya DC, Karbancioglu GF, Ozcelik B (2018) Cold active pectinase, amylase and protease production by yeast isolates obtained from environmental samples. Extremophiles 22:599-606

25. Unver Y, Yildiz M, Taskin M, Arslan NP, Ortucu S (2015) Protease production by free and immobilized cells of the cold-adapted yeast Cryptococcus victoriae CA-8. Bioctal Biotransfor 33:105-110

26. Salwan R, Gulati A, Kasana RC (2010) Phylogenetic diversity of alkaline protease-producing psychrotrophic bacteria from glacier and cold environments of Lahaul and Spiti, India. J Basic Microbiol 50:150-159

27. Tariq A, Reyaz A, Prabakaran JJ (2011) Purification and characterization of 56 KDa cold active protease from Serratia marcescens. Afr J Microbiol Res 5:5841-5847

28. Saba I, Qazi PH, Rather SA, Dar RA, Qadri QA, Ahmad N, Johri S, Taneja SC, Shawl S (2012) Purification and characterization of a cold active alkaline protease from Stenotrophomonas sp., isolated from Kashmir, India. World J Microbiol Biotechnol 28:1071-1079

29. Kuddus M, Ramteke PW (2011) Production optimization of an extracellular cold-active alkaline protease from Stenotrophomonas maltophilia MTCC 7528 and its application in detergent industry. Afr J Microbiol Res 5:809-816

30. Furhan J, Awasthi P, Sharma S (2019a) Biochemical characterization and homology modeling of cold-active alkophilic protease from Northwestern Himalayas and its application in detergent industry. Biocatal Agric Biotechnol 17:726-735

31. Białkowska AM, Krysiak J, Florczak T, Szulczewska KM, Wanarska M, Turkiewicz M (2018) The psychrotrophic yeast Sporobolomyces roseus LOCK 1119 as a source of a highly active aspartic protease for the in vitro production of antioxidant peptides. Biotechnol Appl Biochem 65:726-738

32. Mageswari A, Subramanian P, Chandrasekaran S, Karthikeyan S, Gothandam KM (2017) Systematic functional analysis and application of a cold-active serine protease from a novel Chryseobacterium sp. Food Chem 217:18-27

33. Kim EH, Cho KH, Lee YM, Yim JH, Lee HK, Cho JC, Hong SG (2010b) Diversity of cold-active protease-producing bacteria from arctic terrestrial and marine environments revealed by enrichment culture. J Microbiol 48:426-432

34. Furhan J, Salaria N, Jabeen M, Qadri J (2019b) Partial purification and characterisation of cold-active metalloprotease by Bacillus sp. AP1 from Apharwat peak, Kashmir. Pak J Biotechnol 16:47-54

35. Kim DK, Park HJ, Lee YM, Hong SG, Lee HK, Yim JH (2010a) Screening for cold-active protease-producing bacteria from the culture collection of polar microorganisms and characterization of proteolytic activities. Korean J Microbiol 46:73-79

36. Martínez-Rosales C, Castro-Sowinski S (2011) Antarctic bacterial isolates that produce cold-active extracellular proteases at low temperature but are active and stable at high temperature. Polar Res 30:7123

37. Yang J, Li J, Mai Z, Tian X, Zhang S (2013) Purification, characterization, and gene cloning of a cold-adapted thermolysin-like protease from Halobacillus sp. SCSIO 20089. J Biosci Bioeng 115:628-632

38. Yadav AN, Sachan SG, Verma P, Kaushik R, Saxena AK (2016) Cold active hydrolytic enzymes production by psychrotrophic Bacilli isolated from three sub-glacial lakes of NW Indian Himalayas. J Microbiol 56:294-307

39. de Pascale D et al (2010) PhAP protease from Pseudoalteromonas haloplanktis TAC125: gene cloning, recombinant production in E. coli and enzyme characterization. Polar Sci 4:285-294

40. Papagianni M, Sergelidis D (2014) Purification and biochemical characterization of a novel alkaline protease produced by Penicillium nalgiovense. Appl Biochem Biotechol 172:3926-3938

41. Kawahara H (2017) Cryoprotectants and ice-binding proteins. In: Psychrophiles: from biodiversity to biotechnology. Springer, pp 237-257
42. De Maayer P, Anderson D, Cary C, Cowan DA (2014) Some like it cold: understanding the survival strategies of psychrophiles. EMBO Rep: e201338170

43. Rivkina E, Friedmann E, McKay C, Gilichinsky D (2000) Metabolic activity of permafrost bacteria below the freezing point. Appl Environ Microbiol 66: 3230-3233

44. Schroeter B, Green T, Kappen L, Seppelt R (1994) Carbon dioxide exchange at subzero temperatures. Field measurements on Umbilicaria aprina in Antarctica. Cryptogam Bot 4:233-241

45. Collins M, Buick R (1989) Effect of temperature on the spoilage of stored peas by Rhodotorula glutinis. Food Microbiol 6:135-141

46. Rodrigues D, Tiedje J (2008) Coping with our cold planet. Appl Environ Microbiol 74:1677-1686

47. Piette F, D'Amico S, Mazzucchelli G, Danchin A, Leprince P, Feller G (2011) Life in the cold: a proteomic study of cold-repressed proteins in the Antarctic bacterium Pseudoalteromonas haloplanktis TAC125. Appl Environ Microbiol 77:3881-3883

48. Celik Y, Drori R, Pertaya-Braun N, Altan A, Barton T, Bar-Dolev M, Groisman A, Davies PL, Braslavsky I (2013) Microfluidic experiments reveal that antifreeze proteins bound to ice crystals suffice to prevent their growth. Proc Natl Acad Sci 110:1309-1314

49. Kawahara $H$ (2002) The structures and functions of ice crystal-controlling proteins from bacteria. J Biosci Bioeng 94:492-496

50. Casanueva A, Tuffin M, Cary C, Cowan DA (2010) Molecular adaptations to psychrophily: the impact of 'omic'technologies. Trends Microbiol 18:374-381

51. D'Amico S, Collins T, Marx JC, Feller G, Gerday C (2006) Psychrophilic microorganisms: challenges for life. EMBO Rep 7:385-389

52. Berger F, Morellet N, Menu F, Potier P (1996) Cold shock and cold acclimation proteins in the psychrotrophic bacterium Arthrobacter globiformis SI55. J Bacteriol 178:2999-3007

53. Amaretti A, Raimondi S, Sala M, Roncaglia L, De Lucia M, Leonardi A, Rossi M (2010) Single cell oils of the cold-adapted oleaginous yeast Rhodotorula glacialis DBVPG 4785. Microb Cell Factories 9:73

54. Ochsenreither K, Glück C, Stressler T, Fischer L, Syldatk C (2016) Production strategies and applications of microbial single cell oils. Front Microbiol 7:1539

55. Fonseca F, Meneghel J, Cenard S, Passot S, Morris GJ (2016) Determination of intracellular vitrification temperatures for unicellular micro organisms under conditions relevant for cryopreservation. PLoS One 11:e0152939

56. Deming JW, Young JN (2017) The role of exopolysaccharides in microbial adaptation to cold habitats. In: Psychrophiles: from biodiversity to biotechnology. Springer, pp 259-284

57. Casillo A, Parrilli E, Sannino F, Mitchell DE, Gibson Ml, Marino G, Lanzetta R, Parrilli M, Cosconati S, Novellino E (2017) Structure-activity relationship of the exopolysaccharide from a psychrophilic bacterium: a strategy for cryoprotection. Carbohydr Polym 156:364-371

58. Romero-Romero ML, Inglés-Prieto A, Ibarra-Molero B, Sanchez-Ruiz JM (2011) Highly anomalous energetics of protein cold denaturation linked to folding-unfolding kinetics. PLoS One 6:e23050

59. Wang Q, Hou Y, Xu Z, Miao J, Li G (2008) Optimization of cold-active protease production by the psychrophilic bacterium Colwellia sp. NJ341 with response surface methodology. Bioresour Technol 99:1926-1931

60. Chen K, Mo Q, Liu H, Yuan F, Chai H, Lu F, Zhang H (2018) Identification and characterization of a novel cold-tolerant extracellular protease from Planococcus sp. CGMCC 8088. Extremophiles 22:473-484

61. Margesin R, Dieplinger H, Hofmann J, Sarg B, Lindner H (2005) A cold-active extracellular metalloprotease from Pedobacter cryoconitis - production and properties. Res Microbiol 156:499-505

62. Huston AL, Methe B, Deming JW (2004) Purification, characterization, and sequencing of an extracellular cold-active aminopeptidase produced by marine psychrophile Colwellia psychrerythraea strain 34H. Appl Environ Microbiol 70:3321-3328

63. Salwan R, Kasana RC (2013) Purification and characterization of an extracellular low temperature-active and alkaline stable peptidase from psychrotrophic Acinetobacter sp. MN 12 MTCC (10786). Indian J Microbiol 53:63-69

64. Park HJ, Lee CW, Kim D, Do H, Han SJ, Kim JE, Koo BH, Lee JH, Yim JH (2018) Crystal structure of a cold-active protease (Pro21717) from the psychrophilic bacterium, Pseudoalteromonas arctica PAMC 21717, at $1.4 \AA$ resolution: structural adaptations to cold and functional analysis of a laundry detergent enzyme. PLoS One 13:e0191740

65. Son ES, Kim JI (2002) Purification and characterization of caseinolytic extracellular protease from Bacillus amyloliquefaciens S94. J Microbiol 40:26-32 
66. Kuddus M, Ramteke PW (2008) Purification and properties of cold-active metalloprotease from Curtobacterium luteum and effect of culture conditions on production. Chin J Biotechnol 24:2074-2080

67. Salwan R, Sharma V, Pal M, Kasana RC, Yadav SK, Gulati A (2018) Heterologous expression and structure-function relationship of lowtemperature and alkaline active protease from Acinetobacter sp. IHB B 5011 (MN12). Int J Biol Macromol 107:567-574

68. Yan $B Q$, Chen XL, Hou XY, He H, Zhou BC, Zhang YZ (2009) Molecular analysis of the gene encoding a cold-adapted halophilic subtilase from deep-sea psychrotolerant bacterium Pseudoalteromonas sp. SM9913: cloning, expression, characterization and function analysis of the C-terminal PPC domains. Extremophiles 13:725-733

69. Zhao HY, Feng H (2018) Engineering Bacillus pumilus alkaline serine protease to increase its low-temperature proteolytic activity by directed evolution. BMC Biotechnol 18:34

70. Aghajari N, Van Petegem F, Villeret V, Chessa JP, Gerday C, Haser R, Van Beeumen J (2003) Crystal structures of a psychrophilic metalloprotease reveal new insights into catalysis by cold-adapted proteases. Proteins. 50: 636-647

71. Baghel V, Tripathi RD, Ramteke PW, Gopal K, Dwivedi S, Jain RK, Rai UN, Singh SN (2005) Psychrotrophic proteolytic bacteria from cold environment of Gangotri glacier, Western Himalaya, India. Enzym Microb Technol 36:654-659

72. Yuan Q, Hayashi A, Kitamura Y, Shimada T, Na R, Jin X (2009) Purification and characterization of cold-adapted metalloprotease from deep sea water lactic acid bacteria Enterococcus faecalis TN-9. Int J Biol 1:12

73. Tamaki H, Hanada S, Kamagata Y, Nakamura K, Nomura N, Nakano K, Matsumura M (2003) Flavobacterium limicola sp. nov., a psychrophilic, organic-polymer-degrading bacterium isolated from freshwater sediments. Int J Syst Evol Microbiol 53:519-526

74. He H, Chen X, Li J, Zhang Y, Gao P (2004) Taste improvement of refrigerated meat treated with cold-adapted protease. Food Chem 84:307-311

75. Vazquez SC, Coria SH, Mac Cormack WP (2004) Extracellular proteases from eight psychrotolerant Antarctic strains. Microbiol Res 159:157-166

76. Zeng R, Zhang R, Zhao J, Lin N (2003) Cold-active serine alkaline protease from the psychrophilic bacterium Pseudomonas strain DY-A: enzyme purification and characterization. Extremophiles 7:335-337

77. Zhu H-Y, Tian Y, Hou Y-H, Wang T-h (2009) Purification and characterization of the cold-active alkaline protease from marine cold-adaptive Penicillium chrysogenum FS010. Mol Biol Rep 36:2169

78. Preiss L, Hicks DB, Suzuki S, Meier T, Krulwich TA (2015) Alkaliphilic bacteria with impact on industrial applications, concepts of early life forms, and bioenergetics of ATP synthesis. Front Bioeng Biotechnol 3:75

79. Sarmiento F, Peralta R, Blamey JM (2015) Cold and hot extremozymes: industrial relevance and current trends. Front Bioeng Biotechnol 3:148

80. Dube S, Singh L, Alam S (2001) Proteolytic anaerobic bacteria from lake sediments of Antarctica. Enzym Microb Technol 28:114-121

\section{Publisher's Note}

Springer Nature remains neutral with regard to jurisdictional claims in published maps and institutional affiliations.

\section{Submit your manuscript to a SpringerOpen ${ }^{\circ}$ journal and benefit from:}

- Convenient online submission

- Rigorous peer review

- Open access: articles freely available online

- High visibility within the field

- Retaining the copyright to your article

Submit your next manuscript at $\boldsymbol{\nabla}$ springeropen.com 